\title{
Extension Farmer-Input Linkage System (REFILS) by Agricultural Development Programmes (ADPs) in Nigeria, 1986-2011
}

\author{
Nnadozie A. K. O. ${ }^{1,}$, , Ume S. I. ${ }^{2}$, Isiocha $S .{ }^{3}$, Njoku I. A. ${ }^{1}$ \\ ${ }^{1}$ Department of Marketing, Federal College of Agriculture, Ishiagu Nigeria \\ ${ }^{2}$ Department of Agricultural Extension \& Management, Federal College of Agriculture, Ishiagu Nigeria \\ ${ }^{3}$ Department of Home \& Rural Economics, Federal College of Agriculture, Ishiagu Nigeria
}

\section{Email address:}

akonnadozie@yahoo.com (Nnadozie A. K. O.), goodynjoku@yahoo.com (Njoku I. A.), umesmilesi@gmail.com (Ume S. I.), stellaisiocha@yahoo.com (Isiocha S.)

\section{To cite this article:}

Nnadozie A. K. O., Ume S. I., Isiocha S., Njoku I. A. Extension Farmer-Input Linkage System (REFILS) by Agricultural Development Programmes (ADPs) in Nigeria, 1986-2011. Science Journal of Business and Management. Special Issue: Sustainable Entrepreneurial Developments in Agribusiness. Vol. 3, No. 5-1, 2015, pp. 41-46. doi: 10.11648/j.sjbm.s.2015030501.19

\begin{abstract}
One of the most debilitating problems of research and policy in Agricultural Extension in developing countries like Nigeria is the rate at which available research results are lost. There is a lag of 50 years between discovery of innovations and their effective utilization in the field. The above scenario implicates weak research farmer linkage and exposes inefficient extension service which prevailed in pre and post independent Nigeria before the establishment of a state wide Agricultural development Project (ADPs) in 1986. An active and virile sustainable ADPs anchored on the Research-Extension farmer-input linkage system (REFILS) is a vibrant and veritable extension instrument for effective technology transfer by linking research to policy and development in Nigeria. The characteristics of an efficient and effective agricultural services examined includes ; use of subject matter specialists, motivation of staff, cost effective extension approaches, defined targets or clientele, flexibility and an efficient internal monitoring and evaluation component. Despite identified constraints and the prevailing economic realities, the ADPs REFILS approach has proved an integrated development model in linking research to policy and development in Nigerian agribusiness. This paper examined the REFILS techniques and the strategies that worked for their effectiveness such as the research component, the NGOs input linkage and technology transfer in agricultural business among others.
\end{abstract}

Keywords: Nigerian ADPs, Research Transfer, Policy, Agribusiness-Development, REFILS Strategies

\section{Introduction}

This paper is a review of Research-Extension-FarmerInput Linkage System (REFILS); an umbrella organ that coordinates the research and extension activities of the Agricultural Development Programmes (ADPs) in Nigeria. It is a representation of institutional dynamics of linkage between National Agricultural Research Institutes (NARIS), Agricultural Development Programmes (ADPs), farmers and input agencies. The ADPs has made some significant impacts in the agricultural and rural landscape of Nigeria among which are sustainable revitalized services, human capacity building, technology development, transfer and adoption, input distribution, rural infrastructure development, increased income generation and poverty reduction in Nigeria.
Mechanism to increased farmers access to inputs and research results and timely access to farm inputs were discussed. This involved the emergence of the farming System Research (FSR) and Agricultural Extension and Research Liaison Services (AERLS) of the National Agricultural Research Institutions (Gnarls in 1994 to form the Farming System Research and Extension units (FSR\&E). R.E.F.I.L.S is an organization of Research Extension and input agencies to improve productivity of farmers. The concept of REFILS is that village extension workers pass information to farmers on inputs and market situations.

\section{Problem Statement}

The identified problem was that report on training and extension system showed that farmers rarely have timely access to farm inputs which was implicated for the low 
output of farmers across Nigerian states despite huge investments made in the agricultural extension services. The World Bank (1995), reported that between June 1987 and March 1995, about \$508.1 million World Bank loan was invested in agricultural and environmental projects in Nigeria (Anuebunwa, 2000). Yet, the rural areas where agriculture is practiced have neither reflected this level of investment indicative of its potentials. There was therefore, need to find out the reasons for this gap and how to improve on researchextension effectiveness. Thus, the review of REFILS strategies by ADPs in Nigeria for a period of 25 years (19862011).

The broad objective of the study is to review REFILS strategies by ADPs in Nigeria between 1986 and 2011 while the specific objectives were to:

i. Examine the components of REFILS i.e. technical committee, zonal steering committee, the zonal OFAR, REFILS workshop and technology review meetings.

ii. Determine the strategies of linkage and technology transfer of REFILS, among others in fast tracking agribusiness development across Nigerian states.

iii. Make policy implications based on the findings.

\section{Materials and Method}

The method used in the study is review of related literature and field experiences while content analysis was employed in discussing the findings. In Nigeria, there are 36 state ADPs that have been established by federal and state governments and maintained by the World Bank loan for about 20 years. The Multi State ADP, (MSADP) has 800 Village Extension Agents, 1200 specialists and 400 women groups (VEAs). Approximately a quarter of the above personnel belong to the South Eastern States (Okoli, 1996; Igbokwe, 2002).

\subsection{The REFILS Strategies}

The national agricultural institutes in the six geopolitical zones of Nigeria form the major anchorage with the Universities and other tertiary institutions collaborating with the state Agricultural Development Programmes and input supply agencies mostly Non- governmental organizations in the execution of the REFILS activities.

The approach adopted for research and extension linkage effort in the South- East and South-south geopolitical zones of Nigeria (comprising 11 states) are excellent and include:

i. Diagnostic survey to review constraints,

ii. Prioritizing and evaluating technologies for multi locational trials; demonstration,

iii. Adopting a sequence of action for farming system Research / on station research ( FSR/OFR) research managed trials,

iv. On farm adaptive research (OFAR) extension managed and farmer executed

v. Small plot Adoption Trial (SPAT) extension guided and farmers' demonstration on small plots to publish widely the proven adopted technologies.

These operational strategies cut across various areas as seedlings, seeds, crops, agro-forestry, livestock, soils, processing, mechanization, women in Agriculture (WIA) and training.

NFRA, ADPs linkage strategies in REFILS:

a. Monthly Technology Review Meeting -

i. Facilitation, resource person's participation in field diagnosis and monitoring.

ii. FNT \& SPAT are for Facilitation and Monitoring.

b. Technical Meeting- this include; Zonal Technical Committee, Zonal Steering Committee and Thematic Regional Technical Linkage Meeting.

c. Diagnostic Surveys; which involve Survey limitation, co-ordination of multidisciplinary survey, Recruitment of resource persons and provision of guideline to teams.

d. Training and workshops: These trainings are to upgrade skills of ADP subject matter specialists and field extension agents in collaboration with relevant NARIs. Other activities are thematic supervision of workshops in southern and Northern ADPS; National Annual Thematic workshops on Agro-forestry, land use, crops, livestock, fisheries, WIA and extension service delivery. Annual in - house research institutes reviews and MTRM Resource person's workshops are also strategic.

e. Extension Publications: These include Agro scope, technical bulletin, occasional papers / field manuals-, Conduct of OFAR trials and FNT, etc.

\subsection{The Monthly Technology Review Meeting (MTRM)}

The MTRM according to Unanma (1996), is a forum at which extension staff, through the REFILS mechanism, update the knowledge of the scientists about the farmers' input demand situations. In turn, the research scientists upgrade the technical staff, and input and marketing agencies provide them with information on the supply situation for responding to farmers' reactions to any intervention by extension staff during the last two fortnights.

The main objectives of MTRM are to train subject matter specialists (SMSs) particularly in the production recommendations that extension agents would be teaching farmers over a four week period that usually starts some two or three weeks after the workshop .

\subsection{Characteristics of MTRM Technologies}

The technologies recommended are the specific agricultural practices that farmers are taught by extension staff (Unanma, 1996). The effectiveness of the technology transfer exercise depends on the:

1. Extent to which the technology being promoted help to reduce costs and risk or to increase production.

2. Degree of profitability (benefits/resources cost ratio) at acceptable levels and risks.

3. Skills needed for the adoption.

4. Level of instructions and resources required.

5. Farmers' practices and feasibility to adopt by farmers.

The above are in consideration that farming activities are time-bound. Thus, MRTM ensures that farmers are able to 
capture the progress of technologies being promoted in their fields, so as to address any problem or obtain adequate feed back for research through the SMSs and the EAs/BES for further improvements.

\subsection{FNTS- Fortnightly Training Session}

FNTS are the key components of continuously up-grading and up-dating the professional skills of EAs/BES held for one full day forth- nightly. At each session, the EAs/BES review farmers' reactions to previous recommendations, and are taught chunks of specific practices that would be taught farmers during the coming two weeks. Reports on the farmers 'input and marketing agencies are also represented. The EAs' report field problems or conditions that needed attention in these recommendations or for research investigations. They also discuss and learn from each other's experiences.

\subsection{Zonal (OFAR) on the Farm Adaptive Research}

On station and on farm Research- Farming problems requiring on station experiments are referred to the appropriate research institutions where those solutions are available as on farm applied research (research managed) or on farm adaptive research (OFAR) which is the farmer managed.

\subsection{Small Plot Adoption Technique (SPAT)}

SPAT describes the practice whereby an extension staff in unity with contact farmers, uses the farmers' farm or farmer's meeting places (non-soil based). The extension staff encourage the farmers (farmers group) to initially try the technology in a small plot of $5 \mathrm{~m} \times 5 \mathrm{~m}$ or $10 \mathrm{~m} \times 10 \mathrm{~m}$. In this process, the farmer(s) can compare the small plot with an equivalent plot of his usual practice (Unanma et al., 1991). However, if the specific enterprise technology is completely new, the SPAT concept as a novel idea will apply.

Training: This is regular and continuous. There are more trainings for front-line extension staff, subject matter specialist (SMSs) and scientists at the research institutes and Universities

Filed visits: These are regular and are key features of REFILS continuous field feedback; monitoring and evaluation. The technologies transferred to farmers may be adopted, modified or rejected by farmers. These reactions are feed back, monitoring and evaluation mechanism. Therefore, every actor in REFILS is vital to the success of the system.

Research Institutions in Nigeria: currently, Nigeria has 21 Agricultural research Institutes. About 14 of them are under the management of Agricultural Research Council of Nigeria (ARCN) and 4 are attached to Universities (AESON, 2004; appendix 1).

Components of REFILS: REFILS components include the following;

a. Technical committee is composed of director of technical service in each state ADPs, the headquarters SMSs, Zonal SMSs, zonal extension officer and zonal manager.

b. The zonal steering committee include the head of the region and national food reserve Agency, (PCU/FACU now NFRA), representative of various crop and livestock, fishery components of the coordinating research institutions that have faculty of agriculture, the ADP state director of technical service, extension services, planning, monitoring and evaluation, financial controller and programme manager.

c. Zonal OFAR/REFILS workshop / technical review meeting (TRM) is composed of the following; zonal REFILS -annually while MTRM is monthly held.

ADP Participants:

All SMSs including Women in Agriculture (WIA), Zonal extension officers, director of technical services (DTS), Director of Extension (DES), Zonal manager (ZM), Head of commercial service (RID), Head manpower development (HMRD), Training Officer, Head planning monitoring and evaluation ( once quarterly), Head finance ( once quarterly) and Programme Manager (once quarterly).

National Food Reserve Agency (Fed. Ministry of Agric \& Rural Dept.):

Officers include Regional Adaptive Research Coordinator, Regional coordinator of Extension.

Research Institute / Universities: here comes the team leader (Chairman), four core resource persons from one of the following disciplines - Agronomy, plant protection, livestock, fisheries, Agricultural Extension / Economics, processing and utilization. Other scientists or resource persons may be invited as the need arises.

\section{Results and Discussion}

The achievements of ADPs in the south eastern and south southern Nigeria in the crop sub - sector expanded due to close extension of improved varieties of cassava, yam, maize, cocoyam, egusi (melon) groundnut, rice, cowpea, inter- crops, optimum fertilizer and weed control with the various crop combination and yam, cocoyam mini-sett technique. These have been through REFILS, with the acquisition of new agricultural technologies (New Crop and animal varieties, premium seeds, seedlings, chicks, piglets, kids, fingerlings, apiculture, snails and grass cuter farming).

Ene (1993) estimated that ADPs extension services have reached $4 / 5$ or so percent of rural population in Nigeria and have improved rural infrastructure, extended new farm technologies and increased agricultural productivity. As in 1993 Nigeria agricultural growth was 4.5\%. By 1993, 80\% of Nigerian farmers had adopted improved cassava and / maize inter cropping systems. About $70 \%$ had access to soya bean and $35 \%$ adopted improved yam mini -sett technique.

Obiechina (1996) reported annual growth rate percentage for selected staples in the ADP REFILs impact areas as shown: Cassava (36.30\%); Yam (24.37\%); Cowpea (14.72\%); Millet (14.25\%); Maize (11.68\%); Rice (9.14\%); Sorghum (5.71) and Groundnut (4.52\%) between 1990 and 1995. Obiechina (1996) reported increase on the hectares established by the ADPs through REFILS for seed 
multiplication from about 3,600 hectares in 1987 to an impressive 29,000 hectares. Fertilizer supply to farmers by ADPs increased at an average rate of $34.3 \%$ annually from about 30,000 metric tons nationally in 1985 to 729,000 metric tons in 1990. Thus, a sharp increase of 14.7 million metric tons in 1996.

Also total length of roads constructed and maintained by ADPs per year increased by $9.4 \%$ between 1985 and 1995 while rural water supply also improved. In the areas of farm mechanization, local black smith were trained in the fabrication of simple farm tools and other labour saving devices for both on- farm and post harvesting processing. These helped to improve farm incomes and general living standard of Nigerian rural dwellers. Alasa (2005) reported tremendous yield increases on various crops per hectare as shown; yam $10.45 \mathrm{mt}$ to $14.54 \mathrm{mt}$, cassava $11.98 \mathrm{mt}$ to $16.06 \mathrm{mt}$, maize $1.35 \mathrm{mt}$ to $2.3 \mathrm{mt}$, etc.

IITA (2005) reported that with collaboration, it released over 42 new cassava varieties to farmers across Nigerian states. Eboh (2011) observed that from 1986-90 Nigeria recorded higher annual average agricultural growth $(6.7 \%)$ per annum and poverty reduced from $43 \%$ in 1985 to $34 \%$ in 1992, while, a decline in annual average agricultural growth (2.4\%) per annum from 1990-1996 was accompanied by increased poverty from $34 \%$ to $65 \%$ in 1996. Accordingly, Eboh (2011) agreed that agricultural development in the national policy framework requires synergy between growth-oriented macro-economic policies and sector specific enablers. Hardly can agricultural development take place in the absence of agricultural growth which in turn depends on stable macro- economic and institutional environment. This is because structural transformation requires that agricultural policies and industrial policies must be in pursuit of economic linkages and feedback typified by the ADPs' REFILS Model in Nigeria.

Currently, the development of agricultural economy is pursued within the overarching contexts of Nigeria's vision 2020 economic transformation blueprint and the associated medium term implementation plan 2010- 2013. Agricultural Development is modeled as a strategic component of the overall national propensity ambition of becoming one of the top 20 economies by the year 2020. Nigeria aspires to achieve, in the medium term (2010-2013) average annual
GDP growth rate of $11 \%$ (up from 7\% during 2004- 2009) in the non-oil export which agriculture is the main export product. Agriculture, amidst low and stagnating productivity, accounts for about $41 \%$ of GDP and about $60 \%$ of total employment as manufacturing sector accounts for only 5\% employment in Nigeria (Eboh 2011; Eboh, et al., 2010). Agricultural sector contributed an annual average of more than $32 \%$ of GDP from 2002 - 2007 but its:

- Share of total federal government's spending from 2002-2007 averaged 4.3\%

- Share of total state governments' spending from 2002-2007 averaged 3.6\%

- Share total federal and state governments spending from 2002-2007 average 3.4\%

- However, its share peaked in early mid-1980s at about $5.9 \%$ stagnated to $1.2 \%$ between 1990 and 2000 and then rose to between $3.1-4.4 \%$ between 2001 and 2006 .

- Ratio of agricultural sector spending to agricultural sector GPD averaged 2.8\% from 2002 - 2007

- The long term average of the ratio of agricultural sector expenditure share of GDP to agricultural sector GDP is about 0.07 , indicating that agricultural sector spending has been less than one-tenth of the agricultural share of the GDP.

Table 1 has shown that agriculture's share of employment is 70.8 percent, industry is 10.4 percent and services are 18.8 percent. Agriculture share of GDP (constant prices) is 42.1 above 22.0 for industry and 35.9 for services sectors in 2009 and the real GDP per sector EAP (Naira) for Agriculture was N10, 258.4 lower than N97, 012.7 for industry and N13, 046.3 for services.

Agricultural sector's growth performance could be attributed to the performance of the four agricultural sub sector s, crops, livestock, fisheries and forestry. The crop sub sector had on average the largest share of the growth, followed by livestock, forestry and the fisheries about 85 percent to the agricultural GDP, while the share of the crop sector declined up to the early 1980s, the performance of fisheries saw a steady improvement through the past five decades. But overall, crop remains the dominant agricultural activity in Nigeria. Growth performance of the agriculture sector was therefore, largely driven by the performance of the crop sub-sector, despite its low yields.

Table 1. Nigeria - Selected indicators of structural transformation (in percentage unless otherwise specified).

\begin{tabular}{|c|c|c|c|c|c|c|}
\hline Indicators & 1960 & 1970 & 1980 & 1990 & 2000 & 2009 \\
\hline Agriculture & 64.3 & 44.7 & 20.60 & 32.5 & 35.8 & 42.1 \\
\hline Industry & 5.8 & 19.4 & 34.6 & 43.2 & 37.0 & 22.0 \\
\hline Services & 29.9 & 35.9 & 44.8 & 25.3 & 27.2 & 35.9 \\
\hline (Of which, building and construction ) & 4.5 & 5.2 & 9.7 & 1.6 & 2.0 & $1.8^{\mathrm{c}}$ \\
\hline (of which, wholesale and retrial trade & 12.4 & 12.2 & 20.0 & 13.4 & 13.1 & $17.3^{\mathrm{c}}$ \\
\hline \multicolumn{7}{|l|}{ Share of Employment (E.AP) } \\
\hline Agriculture & 70.8 & 69.8 & 54.0 & 43.00 & 59.5 & 57.9 \\
\hline Services & 18.8 & 17.2 & 38.0 & 50.0 & 37.7 & 38.9 \\
\hline \multicolumn{7}{|l|}{ Real GDP per Sector (E.AP Naira) } \\
\hline Agriculture & 106.6 & 112.2 & 378.6 & 5315.7 & 5271.9 & 10258.4 \\
\hline Industry & 66.0 & 265.5 & 4293.6 & 44750.8 & 115649.3 & 97012.7 \\
\hline
\end{tabular}




\begin{tabular}{|c|c|c|c|c|c|c|}
\hline Indicators & 1960 & 1970 & 1980 & 1990 & 2000 & 2009 \\
\hline Services & 186.6 & 364.8 & 1168.7 & 3666.1 & 6310.1 & 13046.3 \\
\hline \multicolumn{7}{|l|}{ Demographic Transition } \\
\hline Fertility rate ${ }^{\mathrm{b} /}$ & 6.5 & 6.6 & 6.9 & 6.6 & 5.8 & 5.2 \\
\hline Birth rate ( per 1000) & 47.6 & 47.4 & 48.8 & 46.0 & 42.3 & 39.3 \\
\hline Death Rate (per 1000) & 25.9 & 23.6 & 20.2 & 19.9 & 17.8 & 16.2 \\
\hline Annual Population Growth & 2.2 & 2.3 & 3.0 & 2.6 & 2.4 & 2.3 \\
\hline Annual urban Population growth & 7.1 & 4.6 & 5.2 & 4.6 & 4.1 & 3.8 \\
\hline Agglomeration index ${ }^{\mathrm{e} /}$ & 4.8 & 6.9 & 9.6 & 12.2 & 13.5 & 14.9 \\
\hline
\end{tabular}

Note:

a/ Data for 1960 and 1970 derived from Dike (1991, table 2. 21 ), those for 1980 and 1990 are derived from AfDB (2010) and those for 2000 and 2009, which annually refer to 2003 and 2007, are estimated from NBS (2009), Employment refers to economically active population (EAP) and definition of sectors may differ among sources.

b/ Birth per 1,000 women ages 15-19 years

c/ Refers to 2008

d/ Real GDP series were compiled from 1960 -73 using 1962/63 constant basic prices, 1974 using 1977-1978 constant basic and $1981-2008$ using 1990.

\section{Conclusion}

The REFILs strategy has linked the ADPs staff with the Universities and research institutes and also created easy access to farmers acquiring farm inputs. On the other hand, farmers' productivity in the zones have increased while sales by NGOs and marketing inputs have also doubled with higher rates of turnover. Field staff, scientists and researchers are motivated based on the linkage policy recommendation. Thus, based on the empirical evidence, one can infer that agribusiness activities (ditto agricultural entrepreneurship) in Nigeria is basically about $70.8 \%$.

Based on the success and effectiveness of REFILS in technology transfer in the agriculture sector, it is recommended as model for other sectors of the economy for the improvement of the Nigerian Economy in particular and Africa in general.

The authors, therefore, concluded that ADPs' REFILS approach to research policy and technology transfer in Agricultural Development in Nigeria resulted to basically, $70.8 \%$ Entrepreneurial activities in Nigerian agribusiness. This is because a growing and competitive agribusiness sector depends on quality infrastructure, effective macroeconomic policies and access to sustainable financing.

\section{Appendix: Research Institutions in Nigeria}

1. Agricultural Extension and Research Liaison Services, Ahmadu Bello University, Samaru Zaria.

2. Cocoa Research Institute of Nigeria, Oniganbari, Ibadan

3. Forestry Research Institute of Nigeria, Forest Hill, Ibadan

4. National Root Crops Research Institute, Umudike

5. Institute of Agricultural Research and Training, moor plantation, Ibadan

6. Kanji lake Research, Farm Centre Maiduguri

7. Lake Chad Research Institute, Farm Centre Maiduguri
8. Leather Research Institute of Nigeria Zaria

9. National animal Production Research Institute, Ahmadu Bello University, Zaira

10. National Cereals Research Institute, Badeggi Niger state.

11. National Horticultural Research Institute, Idi-shin, Ibadan

12. National Veterinary Research Institute, Vom. Jos

13. Nigeria Institute for Oceanography and Marine Research, Victoria Island, Lagos

14. Nigeria Institute for Oil Palm Research Institute, Benin City

15. 15. Nigeria Institute for Trypasonomiasis, Kaduna

16. Nigeria Stored Products Research Ilorin

17. Rubber Research Institute of Nigeria, Iya Nomo, Benin City

18. Nigeria Fresh Water and Fishery Research Institute, Lokoja

19. Agricultural and Rural management Training Institute, Ilorin.

20. International Institute of Tropical Agriculture, Ibadan.

\section{The Authors Affiliation}

1. Dr. Nnadozie A.K.O. is a lecturer and Head, Department of Marketing; Federal College of Agriculture, Ishiagu Nigeria.

2. Dr. Ume. S. I. is a lecturer and Head, Department of Agricultural Extension and Management, Federal College of Agriculture, Ishiagu Nigeria.

3. Isiocha S.C. is a lecturer and Head, Department of Home and Rural Economics, Federal College of Agriculture, Ishiagu Nigeria.

4. Mr. Njoku I.A. is a lecturer, Marketing Department, Federal College of Agriculture, Ishiagu, Nigeria.

\section{References}

[1] AESON (2004) Research Methods in Agricultural Extension edited by Terry. A. Lowe, Agricultural Extension Society of Nigeria of Nigeria, ARMT, Ilorin 
[2] Anuebunwa F. O. (2000) An overview of REFILS as a technology generation and transfer strategy in south eastern Nigeria. Proceedings of $14^{\text {th }}$ Annual farming System Research and Extension Workshop in South Eastern Nigeria Federal Ministry of Agriculture p48-50.

[3] Alasa H.I (2005) Agricultural Development Programme (ADPs). Tool for agricultural transformation; past and present, perspective. Proceedings of $39^{\text {th }}$ Annual Conference of the Agricultural Society of Nigeria p17

[4] Eboh E.C. (2011) Agricultural Economy of Nigeria : paradoxes and cross roads of multinational nature $56^{\text {th }}$ inaugural lecture of the University of Nigeria delivered on January 27, 2011.

[5] Eboh, E, C Ujah O.C. and Nzeh C.E.P (2010). The Global Financial and Economic Crises as an opportunity to rethink Nigeria's Agriculture Sector Strategy' in Eboh . E.C. and O. Ogbu Global economic crises and Nigeria. taking the right lessons and avoiding the wrong lesson, Enugu : African Institute for Applied Economics.

[6] Ene L.S.O (1993) Directors Welcome Address NRCRI, Umudike. P1-2 proceeding of the $8^{\text {th }}$ ANNUAL Farming System Research and Extension workshop south East Nigeria Federal Ministry of Agriculture.
[7] Igbokwe M.C (2002) Welcome Address by the Acting Director , NRCRI, Umudike: proceedings of $17^{\text {th }}$ Annual Zonal Research - Extension - Farmer-Input Linkage System workshop Southern Nigeria, p4 Federal Ministry of Agriculture and Rural Development.

[8] Obiechina C.O (2003) The Evolving Role of Agricultural Development Programmes (ADPs) in Nigeria in rural poverty reduction; proceedings of the $18^{\text {th }}$ Annual Zonal Research Extension Farmer input linkage System ( REFILS) workshop south East Nigeria p19-44 Federal Ministry of Agriculture and Rural Development.

[9] Okoli P.S.O (1996) Research Extension Farmer- Inputs linkage System Research and Extension Workshop in South Eastern Nig. Federal Ministry of Agriculture p18-21

[10] Unanma R. P. A (1996) Guideline to the sustainability of the MTRNs in Nigerian Southern ADPS: proceeding of $10^{\text {th }}$ Annual Farming System Research and Extension Workshop in South Eastern Nigeria, Federal Ministry of Agriculture p22-24.

[11] Unanma R.P.A, Ereemie S and Turtianem T (1991) On-farm Adaptive Research and Small plot Adoption Techniques: Review of concepts under the unified agricultural extension system. Invited discussion paper at the sixth annual farming system research and extension workshop south east Zone $9^{\text {th }}$ $14^{\text {th }}$ December, NCRI Umudike. 